\title{
Alteridade e comunidades de terreiro
}

\author{
Danielle da Silva Assompção.
}

As comunidades de terreiro ocupam e utilizam de forma permanente, os territórios e recursos naturais como condição para sua reprodução cultural, social, religiosa e econômica. Para isso são aplicadas tradições e práticas ancestrais. Há uma grande importância na inclusão destes povos para a sociedade brasileira. Pois precisamos quebrar tabus e definitivamente acabar com o preconceito e a intolerância. Quando falamos sobre cultura e estilo de vida das comunidades de terreiro, a sociedade em que vivemos nos reporta para uma realidade cercada de preconceitos. Neste sentido cabese ressaltar os princípios de alteridade onde devemos respeitar o que é do outro, o que está no outro. Devemos nos colocar no lugar do outro, percebendo diferenças, porém tendo a capacidade de compreendê-las e respeitálas, sendo ela individualmente ou coletivamente.

Baseado no conceito de etnocentrismo, onde um determinado indivíduo ou grupo de pessoas, que possuem o hábito e caráter social, de discriminar o outro, julgando-se melhor ou pior, seja por causa de sua condição social, hábitos e maneiras, pela sua forma de se vestir, pela sua cultura, ou até mesmo pela sua religião. Ter uma visão etnocêntrica nos permite obter valores culturais que por muitas vezes são direcionados a olhares preconceituosos e infundados. Isso demonstra que por vezes o desconhecimento de determinados hábitos culturais, nos leva ao desrespeito e intolerância por quem é diferente. Este fenômeno infelizmente pode tomar drásticas proporções.

O contexto histórico das comunidades de terreiro nos vincula a tradições de matriz africana e suas ancestralidades, seus valores e conceitos. Esta realidade ainda se faz presente em diversos níveis de nossa sociedade. Neste sentido, quando falamos em saúde nas comunidades de terreiro, o preconceito se eleva a níveis inacreditáveis de diferenciação. As tradições religiosas afro-brasileiras são vistas como tradições de negros e pobres, refletindo situações de conflito envolvendo racismo, intolerância religiosa e discriminação. Apesar de todo preconceito ainda existente em nossa sociedade, existem pessoas as quais praticam o estilo de vida adotado por este tipo de comunidade.

As comunidades de terreiro são espaços destinados não somente a religião. Estas contribuem também para o desenvolvimento social e local, preservando cultura, costumes e o tradicionalismo. Contribuem ainda para o desenvolvimento de projetos sociais, os quais visam à inserção deste povo á sociedade. Nas comunidades de terreiro, são desenvolvidas práticas terapêuticas, com foco nas ações de prevenção e promoção da saúde, visando à melhora do estado geral do indivíduo o qual procura por este serviço, focando no seu bem estar físico e espiritual. Através da cultura praticada nas comunidades de terreiro, ficou claro que tais mundos coexistem, são interdependentes, se completam, constituindo uma unidade cósmica, onde todos os elementos estão conectados entre si. O modo de compreender o mundo e o processo de saúde-doença, através de bases cósmicas, místicas e religiosas, são características destas comunidades. O terreiro, através de suas regras e valores, possibilita a construção de relações na busca perfeita pela qualidade de vida e bem estar daqueles que o procuram e crêem.

Para a Organização Mundial de Saúde o termo "Saúde" é um estado de bem-estar físico, psíquico e mental e isso destaca muito bem o papel das tradições afro-brasileiras, onde a saúde é a harmonia do espírito. Nestas comunidades, são praticados diversos tipos de tratamento para o corpo e para a alma. Procedimentos estes diretamente ligados a ervas medicinais utilizadas para fins curativos ou energizantes.

As ervas medicinais, fazem parte do cotidiano de uma grande parcela da população mundial. Elas são utilizadas como recursos desde a antiguidade até os dias atuais. Muitas destas ervas, já possuem sua eficácia comprovada e as mesmas são utilizadas por esta população. Esta utilização vai desde as tradições de família para família, até mesmo por falta de recursos ao cuidar da saúde ou simplesmente por estilo de vida. A partir do reconhecimento da importância destas ervas 
medicinais como recurso terapêutico, a Organização Mundial da Saúde vem desenvolvendo ações para a inclusão das ervas medicinais na atenção primária em saúde. Esta medida corrobora para a inclusão das comunidades de terreiro neste crescente campo da saúde.

Um exemplo o qual podemos citar que é muito utilizado nas comunidades de terreiro são os banhos de ervas, que para muitos podem não possuir efeitos farmacológicos e serem tratados como placebo, mas para outros são utilizados como fonte energética. Por outro lado, até para a escolha correta das folhas aplicadas aos diversos procedimentos utilizados, há uma metodologia a ser aplicada. Seja ela a realização de um banho de ervas ou a utilização de um simples defumador.

Infelizmente muitas pessoas utilizam este recurso terapêutico de forma inadequada, acreditando que pelo fato de ser um produto natural, não causará alterações prejudicais ao organismo.

Hoje em dia através dos diversos estudos realizados, principalmente os direcionados a área de farmácia, a sociedade vem conseguindo entender a importância destas ervas medicinais. Estes estudos também colaboraram para a desmistificação de preconceitos. Principalmente no que se diz respeito ás comunidades de terreiro. As quais desenvolvem papel fundamental para o crescimento desta área. Podemos destacarainda a fitoterapia que é uma ciência a qual estuda o tratamento das doenças através das plantas medicinais e suas aplicabilidades. Estes estudos contribuem principalmente para conscientização da sociedade atual, mesmo que seja através de leis antirracistas, podemos perceber que já há um reconhecimento dos povos afrobrasileiros.

Os terreiros devem ser vistos como espaços de convivência, fé e espiritualidade e deixar de ser designado como um lugar demoníaco. Estes espaços devem ser respeitados por todos, pois realizam mudanças positivas á qualidade de vida de seus integrantes. Nesta questão não falamos somente em fitoterapia, mas sim, em uma cultura étnico-racial, cercada de valores, diversidade, respeito e costumes de um povo cheio de tradições. Compreender o que se vive em comunidades de terreiro, faz com que possamos entender seus mitos e ritos, crenças e valores, e assim constituir um conjunto de saberes técnico-científicos. Sugerindo a reflexão de nossos atos perante, não só a comunidade de terreiro, mas também perante toda sociedade. O conhecimento advindo de nossos estudos, além de nos tornar pessoas melhores, faz com que possamos reconhecer a devida importância das práticas em saúde tradicionais de matriz africana, respeitando, agregando valores e contribuindo para um mundo muito melhor.

\section{Referências}

CANCIAN V.. A medicina Indígena e do Candomblé. Disponível em: $<$ http:// www.namu.com.br/?q=materias/medicina-indigena-e-do-candomble $>$. Acesso em: 08 de Setembro de 2015

CARVALHO L.B., FREIRE J. C., BOSI M. L. M.. Alteridade radical: implicações para o cuidado em saúde. Disponível em: <http://www.scielo. br/scielo.php?pid=S0103-73312009000300017\&script=sci_arttext $>$. Acesso em: 08 de Setembro de 2015.

GUILOUSKI B., COSTA D. R. D. e SCHLÖGL E.. Tradições religiosas indígenas e afro-brasileiras. Disponível em: $<$ http:// ensinoreligiosonreapucarana.pbworks.com/w/file/fetch/64377452/E.R.\%20 TRADI\%C3\%87\%C3\%95ES\%20RELIGIOSAS\%20E\%20INDIGENAS.

pdf $>$. Acesso em: 08 de Setembro de 2015.

KIAMAZA M. K.. Comunidades Tradicionais de Terreiro. Disponível em: $<$ http://5conferenciaestadualdesans.blogspot.com.br/2011/10/comunidadestradicionais-de-terreiro.html>. Acesso em: 08 de Setembro de 2015.

MAPEANDO O AXÉ. Disponível em: <http://www.mapeandoaxe.org.br/ oprojeto>. Acesso em: 08 de Setembro de 2015

MEIRA C. S.. PLANTAS DO AXÉ E SUA FUNDAMENTAÇÃO RELIGIOSA: um estudo de caso no terreiro de Umbanda "Caboclo Boiadeiro" (fazenda Buraco do Boi - Poções/ Bahia). Disponível em: $<$ http://www.uesb.br/ppgca/dissertacoes/2013/CELIO.pdf $>$. Acesso em: 08

de Setembro de 2015.

NASCIMENTO E. C.. Africanos e Afrobrasileiros: Uma história de lutas por políticas que buscam a anti-desigualdade. Disponível em: $<$ http://arquivo. geledes.org.br/areas-de-atuacao/educacao/lei-10-639-03-e-outras/15233africanos-e-afrobrasileiros-uma-historias-de-lutas-por-politicas-quebuscam-a-anti-desigualdade>. Acesso em: 08 de Setembro de 2015.

SILVA J. M., DACACH S. e LOPES F.. Atagba Cartilha O Cuidar Nos Terreiros. Disponível em: <http://www.ebah.com.br/content/ ABAAAgSPEAB/atagba-cartilha-cuidar-nos-terreiros $>$. Acesso em: 08 de Setembro de 2015 .

VIANA B.. Mapeamento das comunidades tradicionais de terreiro pode ajudar a definir políticas públicas. Disponível em: $<\mathrm{http}$ ://www.fbes.org.br/ index.php?option $=$ com_content $\&$ task $=$ view $\& i d=7374 \&$ Itemid $=62>$. Acesso em: 08 de Setembro de 2015 . 